Çanakkale Araştırmaları Türk Yıllığı

Yll: 13, Bahar 2015, Sayı: 18, ss. 385-410, 100. Yll

\title{
Ağabey ve Kardeşi -Hayat Çizgisi Savaştan Geçen İki Medreseli-
}

\author{
Mustafa ARIKAN"
}

$\ddot{O} z$

Osmanlı Devletinin tarih sahnesinden çekildiği yüzyıl dönümünü yaşayan Türk insanı çok ağır șartlar içinde kalmış; savaşlar ile gelen felaketlere şahit olmuş, bazıları uzun yillar cephelerde savaşmış, esir düşmüss, aileler cephede ya da esaretteki çocuklarının yollarını gözlemişler, şahadet haberleri ya da meçhul akıbetler bu acıları ziyadeleştirmiștir. Verilen milli mücadele sonunda yeni Türk devleti kurulmuş, Türk milleti istiklalini kaybetme tehlikesini bertaraf etmişstir.

Tarihin bu zorlu dönemecini bizzat yașamış; gücü nispetinde mücadelenin içinde olmuş binlerce șahsiyet "tarihin gölgesinde" kalmış, "meşâhir-i meçhûle"ye dâhil olmuşlardir. İște, bu kuşaktan iki kardeș, Konya'll İsa ve Mustafa seferberlik ilanı ile savaşa İstanbuldan katılmış iki medrese talebesidir. İsa gönüllü olarak Çanakkale cephesine gitmiş, er olarak 15. Alay'da savaşmış ve Ziğındere'de șehit olmuştur. Kardeși Mustafa, ihtiyat zabiti olarak Kafkas/ Doğu cephesine sevk edilmiş, 17. Firka 50. Alay'da savaşmış, vurularak esir düşmüş, 1916-1918 yillarını Rusya'da esarette geçirmiştir. Milli Mücadele'de yeniden vatan hizmetine çağrılmış; Batı cephesinde Kafkas Fırkası 13. Alay'da Ağustos 1921'den sonra cephedeki büyük muharebelerin hepsine iştirak etmiştir. Her iki savaș döneminin madalyalı muharibidir.

Medrese tahsili yarım kalan Mustafa, savaștan sonra 1924 yllında muallimlik imtihanını kazanarak köyü Dindebol'a mektep açmak üzere görevlendirilmiş, 1959 yllina kadar memleketi Konya'nın köylerinde binlerce talebe yetiştirmiş̧tir. Köyleri Dindebol'un yüksek tahsil yapan ilk üç genci oğulları İsa, Hayri ve Naci olmuştur. Savaş ylllarında düşmanla olan mücadele, erken cumhuriyet yllarında cehalete karşı devam etmiştir.

Binlerce başka örnek üzerinden olabileceği gibi, Çanakkale şehidi medreseli İsa ve kardeşi Mustafa'dan hareketle, savaș yillarında kaybettiğimiz tahsilli

Yrd. Doç. Dr, Selçuk Üniversitesi Edebiyat Fakültesi Tarih Bölümü, marikan@selcuk.edu.tr 
nesil ve bunun yeni devletin kuruluş ylllarındaki tesiri üzerine bir değerlendirme yapmak imkânı bulunmaktadır.

Anahtar Kelimeler: Çanakkale Savaşı, Seferberlikte Medreseliler, Kafkas Cephesi, Gazi Mustafa Bolay, Çanakkale Şehidi Süleyman oğlu İsa, Savașta Kaybedilen Tahsilli Nesil

\title{
Elder Brother and His Brother
}

-Two Person from Madrasah Whose Lifeline passes through the War-

\begin{abstract}
The Turkish who are at the turn of the century which the Ottoman state retreated from the stage of history, stayed in severe conditions; witnessed disasters because of wars, some of them fought in fronts, was taken prisoner, families watched their sons in the front or captivity, martyr notices or unknown results boosted these pains. The new Turkish state was established after the national struggle, Turkish nation eliminated the danger of losing their independence.

Thousands of people, who experienced this difficult period of history, took part in national struggle as much as they can, stayed "in shadow of history" and got involve "meşahir-i meçhule" (unknown famous). Here, İsa and Musa from Konya, who are two brothers from this generation, are two students of madrasah which joined the war from İstanbul with declaration of mobilization. Isa went to the Gallipoli front voluntarily, fought as private in 15th regiment and martyrized in Ziğındere. His brother Mustafa was sent to Caucasian/Eastern front as reserve officer, fought in 17 th division 50 th regiment, was taken prisoner being shoted, and stayed as prisoner between 1916 and 1918 years. He was called again for national service in national struggle; He participated in all great combats in Caucasian division 13th regiment in Western front after August 1921. He is combatant of medal in either war period.

Mustafa, whose madrasah training was left half finished, was charged to open a school in Dindebol, his village, by passing examination for teachership in 1924. He had trained thousands of students in the villages of his hometown Konya. Three young engaged in higher education of Dindebol, are his sons; İsa, Hayri and Naci. The struggle against the enemy in war years continued against illiteracy in republic years.

As may be thousands of the other examples, based on Gallipoli martyr Isa of madrasah and his brother Mustafa, there is opportunity an evaluating on educated generation who we lost in war years and their effects establishment years of new state.
\end{abstract}

Keywords: Gallipoli War, those from Madrasah in Mobilization, Caucasian Front, Gazi Mustafa Bolay, Gallipoli Martyr İsa of Süleyman's Sons, Educated Generation was Lost in War. 


\section{Giriş}

Osmanlı Devleti’nin 93 Harbi ile uğradığı büyük kayıplar, İkinci Meşrutiyet sonrasının kargaşa ortamı, nihayetinde 1911 yılında Trablusgarp Savaşı'nı müteakip yaşanacak 10 yıllık savaş dönemi, devletin ömrünü tamamladığı ve yeni Türk devletinin doğduğu tarihi süreç olacaktır. Özellikle Balkan Savaşları ve Birinci Dünya Savaşı yılları millete büyük acılar yaşatacaktır.

Trablusgarp ve Balkan Savaşları sonrasında ortaya çıkan tablo Osmanlı'nın milletler mücadelesi ortamı içinde bir siyasal yalnızlık içine düştüğünü gösterecektir. Yalnızlıktan kurtulmak için müttefik arayışları içerisinde geçen 1911-1914 yılların$\mathrm{da}^{1}$, bu arayışın neticesi olarak yapılan anlaşmalarda birçok tavizler verilecektir. ${ }^{2}$ İtilaf ya da İttifak devletleri safında yer alanlar, mesele Osmanlı topraklarını paylaşmak ve sömürgeleştirmek olduğu zaman, bir araya gelmiş ve anlaşmalar yapabilmişlerdir. 15 Haziran 1914 tarihli İngiliz-Alman Anlaşması bunun tipik bir örneğidir. Her iki devlet Osmanlı'ya baskı yapmak ve karşılıklı çıkarlarını kabul ettirmek hususunda anlaşmaktadırlar. ${ }^{3}$ Sadece bu örnek bile; savaşın yapısı ve içinde bulunulan yalnızlığın iyi bir göstergesidir.

Almanya ile 2 Ağustos 1914 tarihinde yapılan ittifak anlaşması sonrasında da başka müttefik arayışları içinde görülen Osmanlı Devleti tarafsızlığını ilan etmiş, savaş dışında kalma durumunu sürdürmek istemiştir. Fakat bu durum, Almanya'nın savaşa girişi sonrasında geçecek birkaç ay içinde yardım taleplerinin geri çevrilmesi ve hatta Ruslar ile anlaşmak gibi tehditlerle devleti karşı karşıya getirecektir. ${ }^{4}$ Nihayetinde Ekim 1914 sonrasında Osmanlı donanmasının Rus limanlarını vurmasıyla büyük savaşa girilecektir.

Doğu/Kafkas, Çanakkale, Irak, Suriye/Filistin, Hicaz, Yemen, Kanal gibi birçok cephede dört yıl sürecek olan büyük savaş için ilan edilen seferberlikte Türk milleti, cephe ve cephe gerisinde bu zor yılların sıkıntısını, acılarını yaşayacaktır. Özelikle Anadolu bu acıların ve sıkıntıların yoğun yaşandığı ve devlet için asker deposu vazifesi yapan yer olacaktır. Aileler evlatlarını cephelerde şehit verecek, bazen kardeşler hatta baba-oğul birlikte askerlik vazifelerini yapacaklardır. Kimileri esir düşecek, memleketinden çok uzaklarda yıllarca esaret hayatının bitmesini bekleyecektir. Cepheden ya da esaretten sağ dönebilenleri, Milli Mücadele yıllarında anavatanın savunulması, istiklali kaybetme tehlikesinin bertaraf edilmesi vazifesi bekleyecektir.

1 Ahmet Hurşit Tolon, Birinci Dünya savaşı Sırasında Taksim Anlaşmaları ve Sevr'e Giden Yol, Atatürk Araştırma Merkezi Yayını, Ankara 2016, s. 28-30

2 Rifat Uçarol, Siyasi Tarih (1789-1994), 4. Bask1, Filiz Kitabevi, İstanbul 1995, s. 454-456

3 Uçarol, Siyasi Tarih, s. 456

4 Mustafa Aksakal, Harb-i Umumi Eşiğinde Osmanlı Devleti Son Savaşına Nasıl Girdi, İstanbul Bilgi Üniversitesi Yayını, İstanbul 2010, s.222- 223. 
Seferberlik ve Milli Mücadele yıllarında askerlik yaşındaki oğullarını cepheye gönderen, birisini Çanakkale'de șehit veren, diğerinin esaretten ve sonra yine cepheden dönüşünü bekleyen Konya vilayeti Ermenek kazası Dindebol köyünden Haciisaoğullarından Süleyman Efendi ve oğulları İsa ile Mustafa'nın hikayesi, ${ }^{5}$ bu zor yılların nasıl yaşandığına verilebilecek binlerce örnekten sadece bir tanesidir.

\section{Haciisaoğulları}

Mustafa Bolay, Milli Savunma Bakanlığı ve Konya İl Milli Eğitim Müdürlüğü Arşivlerinde bulunan belgelerde, ailesinin lakabını "Haciisaoğulları" ya da "Hactisaefendioğulları" şeklinde belirtmiştir. Soyadı kanunun kabulünden sonra aile, köylerine izafeten "Bolay" soyadını almıştır. Aile Konya'da Bolaylar olarak tanınmaktadır. ${ }^{6}$

Savaş yıllarında aile lakabına adını veren, İsa ve Mustafa'nın dedeleri Büyük Hacı İsa Efendi'dir. Ayrıca aile şeceresinde, ${ }^{7}$ dede Büyük Hacı İsa Efendi'den başka onun da dedeleri arasında üç ayrı Hacı İsa Efendiye daha rastlanmaktadır. Şecerede adı geçen ilk Hacı İsa Efendi'nin, silsileye göre 16. Yüzyıl ortalarında yaşamıș olması muhtemeldir.

Hattat Hacı İsa Efendi, Kümbet Patlatan ya da Abalı Hoca olarak bilinen ${ }^{8}$ ve yine kendisi de hattat olan Büyük Hacı İsa Efendi'nin dedesidir. Babası ulemadan Hacı Yusuf Efendi'dir. Tahsiline Bolay'da başlamış, daha sonra Hadim'e gelerek Hz. Hadimi'nin talebesi olmuş, ondan icazet almıştır. Bilgisi ve güçlü hitabeti ile dikkat çekmiş, talebe yetiştirmiştir. Sülüs, nesih ve ta'lik yazmıștır. 1169/1755'de Hadim'de ta'lik yazı ile kaleme alınmış; Besmele Risalesi, Tertilü'l-Kur'ân Risalesi, Vezâifü̉lMevta li-Hadimî Risalesi, Duhan Risalesi tespit edilebilen eserlerinden bazılarıdır.

Büyük Hacı İsa Efendi 1812-1875 yılları arasında yaşamıştır. Müderris, aynı za-

5 İsa'nın hayatı ve şahadeti, Mustafa'nın savaş yılları ve sonrasındaki hayatlarının yazımında özellikle Milli Savunma Bakanlığı Arşivinde bulunan 10680 numaralı şahsi dosya, Ermenek Askerlik Şubesi Başkanlığı'nın 8606, 6252 ve 6254 numaralı Kütük Künye Defterleri; aynı şubenin 9248 numaralı Silahaltı Defteri ve Birinci Dünya savaşına ait 2. Kolordu'nun 2 numaralı Zayiat Defteri'nden istifade ile hazırlanan 04 Ekim 2012 tarih ve 4860 sayı ile 14 Haziran 2013 tarih ve 2958 sayılı Askeri Safahat Belgelerinden istifade edilmiștir. Bu bilgiler, Konya İl Milli Eğitim Müdürlüğü Arşivi'nden temin edilen Mustafa Bolay'a ait 253 sicil nolu dosyada yer alan belgeler ve aileden İsa Ruhi Bolay, Süleyman Hayri Bolay, Zehra Koçak ve Sıdıka Yağcı ile 2013-2014 yıllarında yapılan görüșmelerde elde edilen bilgiler ve dedem Mustafa Bolay hakkında annem Merhume Huriye Arıkan ve babam Merhum Mehmet Kamil Arıkan'dan dinlediklerim ve bizzat müşahedelerimle takviye edilmişlerdir. (YN)

6 Mustafa Arıkan, “Bolaylar", Konya Ansiklopedisi, C. 2, Konya 2011, s. 154-158

7 İsa ve Mustafa'nın amcazadesi Kadı Mehmet Emin'in büyük oğlu Mehmet Berati Bolay (01.07.191412.02.1990) tarafindan 1962-1985 yılları arasında yazılı kaynaklar ve aileden edinilen bilgiler ile oluşturulan bu șecere 245 sayfalık bir deftere yazılmıș ve sonuna da aile soyadlarına göre bir indeks eklenmiştir. Bolay Şeceresi adı verilen bu belgenin bir sureti özel arşivimizde mevcuttur. (MA)

8 Kümbet Patlatan lakabı, Karaman'da bir vaazı sırasında cami kubbesindeki çökme; Abalı Hoca lakabı ise, bazen siyah, uzun bir aba giymesi dolayısıyla verilmiştir.

9 Veli Sabri Uyar, "Hattatlar Armağanı", Konya, Sayı 125-126, Mart_Nisan 1949, Yıl XIII, s.24-25. 
manda hattattır. Halk arasında Abalı Hoca ve Kümbet Patlatan lakaplarıla da tanınmıştır. Nakşibendi Halidî Şeyhi Bozkır'lı Memiş Efendi'nin (Çelik 2008) ilk halifesidir. 1841 yılında bir Delâil-i Hayrat yazmıștır. Bu eser, aile tarafından halen muhafaza edilmektedir. Bolay'da medrese açmış ve burada talebe yetiştirmiştir. Karaman, Konya ve İstanbul'da vaazlar vermiştir. Kabri Bolay'dadır. ${ }^{10}$

İsa ve Mustafánın babası Süleyman Efendi 1848 yılında Bolay'da doğmuştur. Büyük Hacı İsa Efendi'nin sekiz çocuğu, altı oğlundan birisidir. "hafiz ve müttaki" bir kimsedir. ${ }^{11}$ Babası tarafından yetiştirildiği ve Konya medreselerinden icazet aldığına dair bilgiler mevcuttur ve "hoca" olarak nitelenmektedir. ${ }^{12}$ Kardeşi Mehmet Hulusi, Konya'ya göçmelerini tavsiye etmiş, geçim endişesi ile bu durum gerçekleşmemiştir. 1902 yllında $^{13}$ diğer kardeşi Hasan Efendi’nin daveti üzerine, Bolay yakınlarındaki Ermenek'e bağlı Dindebol (Katranlı) köyüne yerleşmiştir. 2 Ocak 1935 tarihinde vefat etmiştir.

Hoca Süleyman Efendi ve Fatma Hanım'n üç erkek, üçü kız altı çocuğu olmuştur. İsa ve Mustafa'dan başka, diğer oğlu Osman (1901-1927) ve kızlarından Huriye (1882-1907) genç yaşta ölmüşlerdir. Diğer kızı Şerife (1881-1859) hiç evlenmemiş, ölünceye kadar kardeşi Mustafa'nın yanında kalmıştır. Nüfus kayıt örneğinde ve diğer belgelerde Mustafa'nın doğum tarihi 1310/1894 olarak geçmektedir. Onun gün ve ay belirten tek doğum tarihini kendisi zikretmektedir. Öğretmenlik sicil dosyasında, 1924 yılında kendi el yazısı ile doldurulmuş tercüme-i hal varakasında bu tarih 10 Mart 1310 (22 Mart 1894 Perşembe) olarak belirtilmiştir. ${ }^{14}$

\section{Çanakkale Gönüllüsü İsa ve Şahadeti}

Ermenek Nüfus Müdürlüğünün 1930'lu yllarda geçirdiği bir yangın sebebiyle, kütükler bu tarihten sonra yeniden oluşturulmuştur. Bu sebeple İsa'nın ismine nüfus kayıtlarında rastlanmamaktadır.

Arşiv kayıtları ve şeceredeki bilgilere göre 1303/1887 doğumludur. İlk tahsili babasından ve daha sonra Konya'da almıştır. Sonra İstanbul'da medrese tahsiline devam etmiștir. Tahsiline dair tek belge bir icazetnamedir. 1914 yll C.ahir ikinci onunda

10 Mahmut Sural , “50 Yıl Önceden Bu Yana Her Yönüyle Konya”, Yeni Konya, 19 Eylül 1975, s. 3; Uyar, Hattatlar Armağani, s. 24-25

11 "Prof. Dr. Süleyman Hayri Bolay İle Söyleși” (Haz. Ethem Cebecioğlu, Vahit Göktaş, Sevim Yılmaz), Tasavvuf, Yll: 9, Sayı: 22 (Temmuz-Aralık 2008), s.393

12 Bolay Şeceresi, s. 123

13 Prof. Dr. Süleyman Hayri Bolay, kendisi ile yapılan söyleşide Dindebol'a göç tarihi olarak 1900 yılını zikretmektedir. 1902 tarihi, Mustafa Bolay tarafından sicil dosyasındaki bir tahkikat evrakında iki yerde beyan edilmektedir. Dolayısıyla bu tarihin 1902 olarak tashihi gerekmektedir.

14 Konya İl Milli Eğitim Müdürlüğü Arşivi, Sicil Dosya Nu. (KIMEM A SDN) 253 
(Mayıs ortaları) El-Hafız Mustafa Zühdi bin El-Hacı Hüseyin El-Akçaabadî tarafından verilen bu icazetnamede ismi İsa bin Süleyman Efendi el-Ermenakî olarak kaydedilmiștir. ${ }^{15}$

İcazetnameyi veren Akçaabatlı Kurtoğlu namılla bilinen Hacı Hüseyin Efendi'nin oğlu Mustafa Efendi, Sicill-i Ahval Defteri'ndeki bilgiye göre 1207/1870 doğumludur. 1891 yılında İstanbul'a gelmiş tahsiline orada devam etmiş, 1904'te Darülfünun Ulum-1 Diniyye-i Aliye Şubesinden ikincilikle mezun olmuştur. 1908'de Davutpaşa İdadisinde Arapça mualimliğine tayin edilmiştir. Gümüş maarif nişanıyla ödüllendirilmiştir. ${ }^{16}$

Yeğeni Süleyman Hayri Bolay'in, şehit amcasının Süleymaniye Medresesi'nden yüksek seviyede tahsil sahibi olduğuna dair verdiği şifahi bilgiyi, Kurtoğlu Mustafa Zühtü Efendi'nin talebesi olma durumu teyit etmektedir. İstanbul Edirnekapı Şehitliği'ndeki mezar taşı kitabesinde "Süleymaniye Dersiâmlarından Akçaabatlı Hafiz Mustafa Zühdü Özkurt Kurtoğlu Şişman Hoca Ayaklı Kütüphane 1871-1941” ibaresi mevcuttur. ${ }^{17}$

İsa, yeğeni Zehra Koçak'in ifadesine göre, seferberlik öncesinde Karaman'a vaiz olarak tayin edilmiştir. Burada verdiği vaazlarıyla, halka, dedesi Büyük Hacı İsa Efendi'yi hatırlatmış, cemaatin hayranlığını kazanmıștır.

Seferberliğin ilanını müteakip köyüne gelmiş, bir ay kadar burada kalmıș ve sonra İstanbul'a dönmüştür. Köyün gençleri ile birlikte kına yakılarak askere gönderilmişlerdir. Şehitler Listesindeki kayda göre ${ }^{18}$ İstanbul'da Süleymaniye Askerlik Şubesinde silah altına alınmıştır. Bu durum da, Süleymaniye Medresesi ile irtibatının bir diğer işareti olarak kabul edilmelidir.

Medrese yüksek tahsiline sahip olmasına rağmen, kayıtlarda İsa'nın er olarak askere alındığı görülmektedir. Bu durum, Harbiye Nezareti'nin 1914 yllındaki bir uygulamasından kaynaklanmış; 1887 doğumlu ve 27 yaşından büyük olanlar, ihtiyat zabit vekili olarak değerlendirilmemiştir. ${ }^{19}$

Kardeşi Mustafa'dan menkul bilgiye göre ise; önceleri cephe gerisinde bir levazım birliğinde askerlik yapmıștır. Çanakkale kara savaşlarının başlamasından sonra, içinde bulunduğu şartlardan memnun olmaması sebebiyle, gönüllü olarak cepheye

15 Bak. Ek 1

16 Şeriyye Sicilleri Arşivi, Sicill-i Ahval Defteri, C. 4, s. 7; Sadık Albayrak, Son Devir Osmanlı Uleması (İlmiye Ricalinin Teracim-i Ahvâli), C. 3, İstanbul Büyükşehir Belediyesi Yayınları, İstanbul 1996, s. 391-392

17 Mezarın bir fotoğrafını gönderme lütfunda bulunan Adnan Özkurt Bey’e müteşekkirim. (YN)

18 http://www.msb.gov.tr/arsiv/phpscr/Sehitler.php

19 İsmail Sabah, Çanakkale Savaşlarının Eğitim Kurumuna Etkisi (1914-1916), Yayınlanmamıș Yüksek Lisans Tezi, ÇOMMÜ Eğitim Bilimleri Enstitüsü, Çanakkale 2013, s. 54-55 
gitmek istemiş ve 2. Kolordu 5. Fırka 15. Alay 3. Tabur 11. Bölük'te görev almıştır. 5 Temmuz 1915 Zı̆ğındere taarruzunda şehit olmuştur. ${ }^{20}$

Bilindiği üzere; 28 Haziran-5 Temmuz tarihleri arasında vuku bulan muharebelerde; 5. Tümen Kuzey Grubu ihtiyatından Güneye kaydırılmış ve başta 5. Ordu Komutanı Liman von Sanders ve 2. Kolordu komutanı Korg. Weber'in yanlış ve ısrarları sonucunda Çanakkale muharebelerinin en kanlı çarpışmaları cereyan etmiş, 1,5 kilometrelik alanda beş tümen savaşa sokulmuştur. İsa'nın birliği taarruzda Zı ğındere'nin doğusunda görev yapmıştır. İngiliz makinalı tüfek ve top atışları, tel örgüler nedeniyle 50. Alay duraklamış ve savunma savaşı yapmıştır. Weber'in komutasındaki kolordu burada 8 Mayıs-5 Temmuz tarihleri arasında 15.883 zayiat vermiştir. Weber, başarısızlığı sebebiyle görevini 9 Temmuz'da Vehip Paşa'ya bırakacaktır. ${ }^{21}$

Şahadetinin bir gün öncesinde babasının rüyasına giren İsa ona;

"Yönüm döndüm sizden yana

Kurban lâzım bizden yana” sözleriyle seslenmiş ve adeta şahadetini haber vermiștir. ${ }^{22}$

Medrese tahsilli İsa 5 Temmuz 1915 Ziğındere taarruzunda böylece vatan topraklarına karışmış, kaybedilen tahsilli nesil saflarındaki yerini almıştır.

\section{Medrese Talebesi Mustafa}

Mustafa ağabeyinden 7 yaş küçüktür; öğretmenlik sicil dosyasında, 1924 yılında kendi el yazısı ile doldurulmuş tercüme-i hal varakasında bu tarih 10 Mart 1310 (22 Mart 1894) olarak belirtilmiştir. O da ilk dini bilgilerini babasından almıştır. Maarif arşivindeki sicil dosyasında bulunan ve kendisi tarafından verilen bilgilere göre 1911 yılında Konya’ya gelmiş ve Mahmudiye Mekteb-i İptidaisi’nde öğrenime başlamıştır. Türkçe okuyup-yazmayı burada öğrenmiştir. Nisan 1913’te İstanbul'a ağabeyinin yanına gönderilmiş ve Sultanahmet Medresesi'ne kaydolmuştur. ${ }^{23}$

20 Kolordu Zayiat Defteri'nde şahadet tarihi 22 Haziran 1331 olarak kaydedildiği askeri safahat belgesinden anlaşılmaktadır. Bu tarih Milli Savunma bakanlığı tarafından yayınlanan Şehitlerimiz, C. 3, Ankara 1998, s. 314'te 22.4.1915; http://www.msb.gov.tr/arsiv/phpscr/Sehitler.php'de 22.4 .1331 olarak gösterilmektedir.

215 Temmuz Zığındere taarruzu hakkında bak. Birinci Dünya Harbi'nde Türk Harbi V. Cilt Canakkale Cephesi Harekâtı 1nci, 2nci ve 3ncü Kitapların Özetlenmiş Tarihi (Haziran 1914-9 Ocak 1916), ATASE Yayınları, Ankara 1997, s. 168-170

22 Süleyman Efendi'nin gördüğü bu rüya, Mustafa Bolay'ın çocukları ve torunları tarafından sıklıkla konuşulur, hatırlatılır. (YN)

23 İkinci Meşrutiyet sonrasında medreselerin ıslahı cümlesinden Şeyhülislam Mustafa Hayri Efendi’nin çalışmaları neticesinde, çıkarılan Islah-ı Medaris Nizamnamesi ile, düzenlemeye İstanbul'dan başlanarak bütün medreseler Darü'l-hilafeti'l-aliyye Medresesi adı altında birleştirilmiştir. Gerekli görülen 12 senelik tahsil süresi Tali-i Kısm-1 Evvel, Tali-i Kısm-1 Sani ve Ali Kısım olarak üç devreye ayrılmıştır. Tali sınıflara 260, Ali sınıflara ise 200 talebe alınması kararlaştırılmıştır. Her sınıf da dört şubeye bölünmüștür. Sultan Ahmet Medresesi, yapılan düzenlemede Ayasofya-yı Kebir, Cafer Ağa (Soğuk- 
Mustafa 330 senesi Muharrem/Kasım ayında yeni teşkil edilen medresenin Tali kısm-1 evvel dördüncü sınıfına kabul olunduğunu ve 28 Haziran 1915 tarihine kadar aynı sınıfta okuduğunu beyan etmektedir. ${ }^{24}$

Millî Mücadele sonrasında aldığı tasdikname belgesinden, kendisinin bu sınıfa 2 Ocak 1915 tarihinde kabul edildiği, 334 numaralı talebe olduğu, beşinci sınıfa terfi ettiği aldığı ders ve notları gösteren listenin altında belirtilmiştir. ${ }^{25}$ Aldığı dersler ve başarı durumu şu şekildedir:

"Hadis-i Şerif 10 , Fıkıh: Nikah, Talak, Feraiz 10, Nahv 10 Birinci, Mükaleme ve Hitabet-i Arabiye 10, Hitabet ve Mev'iza 10 Şayan-ı Takdir, Türkçe Tatbikat ve Kitabet 10 Íkinci, Muhtasar Tarih-i Osmani 10, Hesab-ı Nazari 10, Cebir 10, Usul Defteri 10, Hendese 10 Şayan-ı Takdir, Mevalid-i Selase ve Malumat-ı Ziraiye 10, Muhtasar Hikmet-i Tabiiye 10 Malumat-ı Kanuniye 9 Yekün: 139 Aliyyülala Derecede Terfi”

Yukarıdaki listede görüldüğü üzere, bazı derslerde sınıfının birincisi ya da ikincisidir. Yine bazı derslerin başarı durumu şayan-ı takdir ifadesiyle değerlendirilmiştir.

Medrese talebesi Mustafa'nın bu başarılı tahsil hayatı, devletin Birinci Dünya Savaşına girmesi ve seferberlik sebebiyle 14 Temmuz 1915 tarihinde askere alınmasıyla nihayete erecektir.

\section{Doğu/Kafkas Cephesi ve Esaret}

Seferberliğin ilanı ile birlikte mükellefiyet yaş aralığı 20-45 olarak tespit edilmişti. Zamanla muafiyet haklarında kısıtlayıcı kararlar alınan medrese öğrencilerinin muafiyeti savaş zamanında tamamen ortadan kaldırıldı. Birçok cephede savaşmak zorunda kalan Türk ordusu Şubat 1915'te ihtiyat zabit namzetliği alt yaş sınırını 18'e indirdi, bu sınır 1916 Eylülünde 17 yaşa düştü. Savaş boyunca silah altına alınanların sayısı 10 bine yaklaştı. ${ }^{26}$ Mektep ve medreselerin sınıfları adeta boşaldı. Darülhilafe Medresesine ait bir yoklama defterinde 1915 yılı içinde 31 kişi olan sınıf mevcudunun 2'ye düşmesi ve isimlerin karşısında askere gittiklerinin belirtilmesi, bu durumu ifade eden güzel bir örnektir. ${ }^{27}$

kuyu), Valide Sultan (Vani Efendi), Hacı Beşir Ağa (Bâbıâli) medreseleri ile birlikte Taliye kısmının 2. sınıfını teşkil etmiştir. Bak. Mübahat Kütükoğlu, “Darü’l Hilafeti'l Aliyye medresesi ve Kuruluşu Arefesinde İstanbul Medreseleri", İslam Tetkikleri Enstitüsü Dergisi, S. 7/1-2'den ayrı basım, İstanbul 1978, s. 3-4

KİMEMA, SDN 253

Bak. Ek 2

Mehmet Beşikçi, “'Ihtiyat Zabiti’nden 'Yedek Subay'a: Osmanlı'dan Cumhuriyet'e Bir Zorunlu Askerlik Kategorisi Olarak Yedek Subaylık ve Yedek Subaylar, 1891-1930”, Tarih ve Toplum, Güz 2011, s. 45-89

27 Lokman Erdemir, Çanakkale Bir Milletin Varoluş Destanı, Çamlıca Yayınları, İstanbul 2011, s. 126129 
Mustafa, ağabeyi İsa'nın şahadetinden bir hafta sonra 13 Temmuz 1915'te askere alınmış ve Yakacık talimgâhında üç buçuk ay kalmıştır. ${ }^{28} 3$ Kasım 1915'te Kafkas Cephesine sevk edilmiştir. 23 Ocak 1916'da Erzurum Depo Talimgâhına intikal etmiştir. Ermenek Askerlik Şubesi Silahaltı Defterindeki kayda göre 1 Mart 1916'da halen buradadır. Daha sonra 4. Kolordu 17. Firka 50. Alay 3. Tabur 10. Bölük Takım zabitliğine tayin edilmiştir. ${ }^{29}$ Esir düşeceği 4 Ağustos 1916 tarihine kadar 3. Ordu bölgesinde Erzurum-Erzincan civarında savaşmıştır.

30 Mayıs-15 Haziran 1916 tarihleri arasında Mamahatun Muharebesine iştirak etmiş, ${ }^{30}$ Güllüce'de gösterdiği yararlığa binaen harp madalyası ile taltif olunmuştur. ${ }^{31}$ Muharebe esnasında komutanlarının sığınak dışına çıkmaması ikazlarını dinlemeyerek vazifesini yapmış; sığınağa döndüğü vakit birkaç merminin kaputunun eteklerini delip geçtiğini görmüștür. Bu muharebelerin ne kadar zor şartlarda vuku bulduğu, Mustafa ve arkadaşlarının hangi zorluklara göğüs gerdiği; tümeninin asker mevcudu ve bu mevcuda yapılması gereken takviye/ihtiyacı belirten rakamlara bakılarak anlaşlabilir: Subay 211/63, Piyade 2908/8084 Makineli Tüfek 6, Top 3. 50. Alayın mevcudu ise sadece 917'dir. Mustafa'nın esir düștüğü tarihte tümenin piyade mevcudu, alay mevcudunun da altına 723'e düşecektir. ${ }^{32}$

4-5 Ağustos 1916'da Rus Kafkas Ordusunun taarruzunda Erzincan yakınlarında Ziyarettepe'de vurularak esir olacaktır. ${ }^{33} \mathrm{Bu}$ tarihten sonra 2 yll sürecek Rusya'daki esaret hayatı başlayacaktır.

\section{Esaret}

Seferberlik yllarında silah altına alınan 2.850 .000 askerin savaş sonunda 2.290.000'i savaş dışı kalmıştır. Bunların 360 bine yakını esir ve kayıplardır. Esir sayısı ise 200 bin civarında tahmin edilmektedir. ${ }^{34}$ Hilal-i Ahmer Murahhası Akçura'ya göre bunların 60-70 bini Rus esiridir. ${ }^{35}$ Kutlu ve Taşkıran bu sayıyı 65 bin olarak vermek-

28 Bu talimgâhlar hakkında en geniş bilgiye bir hatırat- romanda rastlamaktayız. Burhan Cahit Morkaya'nın İhtiyat Zabiti isimli romanının ilk 86 sayfası, İstanbul'daki talimgâh hatıralarıdır. Bak. Burhan Cahit Morkaya, İhtiyat Zabiti, Kanaat Kütüphanesi, İstanbul 1933

KİMEMA, SDN 253'te yer alan Memurin Tercüme-i Hal Varakası'nda kendisi 11. Bölük olarak zikretmektedir.

30 Askeri Safahat Belgesi, 04 Ekim 2012/4860

31 Memurin Tercüme-i Hal Varakası, KİMEMA, SDN 253, s. 2

32 17. Piyade Tümeni ve 50 Alay ile ilgili rakamlar için bak. Birinci Dünya Harbinde Türk Harbi Kafkas Cephesi 3ncü Ordu Harekatı C II, ATASE Yayını, Ankara 1993, s. 223, 230, 377

33 Askeri Safahat Belgesi, 04 Ekim 2012/4860

34 Birinci Dünya Savaşında Osmanlı zayiatı için bak. Edward J. Erickson, Size Ölmeyi Emrediyorum Birinci Dünya Savaşı'nda Osmanlı Ordusu, Kitap Yayınevi, 2. Baskı, İstanbul 2003, s. 309-315

Rusya Üsera Murahhası Yusuf Akçura Bey’in Raporu, Dersaadet 1335, s. 3 
tedir. ${ }^{36}$ Birinci Dünya Savaşı’nda Türk esirleri üzerine çalışmaları bulunan Yanıkdağ, son zamanlarda tespit edilen belgeler ışığında bu rakamın 90 bin civarında olabileceğini ileri sürmektedir. ${ }^{37}$ Kutlu'nun tespitine göre (Rusya'daki Türk esirleri konusunda en yetkin araştırmadır. Maalesef basılmamıştır.); Kafkasyada 14, Ukrayna'da 5, Rusya'da 34, Sibirya"da 28; Mançurya'da 3 ve Dış Moğolistan'da 1 esir kampı mevcuttur. $^{38}$

İhtiyat zabiti Mustafa'nın esaret hayatına dair bilgileri, kendisi ile 1997 yılında yapılan bir mülakatta anlattıklarından öğrenmekteyiz. ${ }^{39}$

Sol kalçasından şarapnel yarası alarak esir düşen Mustafa, atlı arabalarla önce Trabzon'a götürülmüş, 11 gün yaralarına bakan olmamış, yaralılar ızdırap içinde kıvranmış durmuşlardır. Daha sonra Batum’a nakledilmiş, burada 85 gün hastanede yatmış, tedavi görmüştür. Oradan karargâha, daha sonra da Tiflis'e götürülmüşlerdir. Tiflis'te 15 gün kalmıştır. ${ }^{40}$

Türk esirlerinin sevk sırasında yaşadıkları, hastanelerde maruz kaldıkları kötü muameleler, özellikle Ermenilerin intikam duygusuyla hareket etmeleri birçok askerimizin henüz yollarda hayatını kaybetmesinin sebebi olmuştur. ${ }^{41}$

$\mathrm{Bu}$ kötü muamelelerin şahidi ve bazen muhatabı olan Mustafa, hayatı boyunca esaret dönemi için konuşmaktan kaçınmış, bu hatırlayışlar onu üzüntüye sevk etmiştir. Burada madalya ve beratına, özel eşyalarına el konulmuştur. Özellikle Ermenilerin Türk esirlerine yaptıkları bu üzüntünün asıl sebebidir. ${ }^{42}$ ATASE Arşivinde bulunan

36 Cemil Kutlu, I. Dünya Savaşında Rusya'daki Türk Esirleri ve Bunların Yurda Döndürülme Faaliyetleri, Yayınlanmamış Doktora Tezi, Atatürk Üniversitesi Atatürk İlkeleri ve İnkılap Tarihi Enstitüsü, Erzurum 1997, s. 7; Cemalettin Taşkıran, Ana Ben Ölmedim 1. Dünya Savaşında Türk Esirleri, Türkiye İş Bankası Yayınları, İstanbul 2001, s. 50-51

37 Rusya'daki esir sayısı hakkındaki yeni bilgiler için bak. Yücel Yanıkdağ, "Rusya'daki 90 bin Osmanlı savaş esiri ve Sarıkamış Muharebesi”, Taraf, 7 Ocak 2015, s. 10

38 Kutlu, Rusya'daki Türk Esirleri, s. 70-79. Kutlu'nun isimlerini verdiği kampların dışında Rusya'da başka esir kamplarının da bulunması muhtemeldir. (YN)

39 Said Nursi ile olan esaret arkadaşlığı dolayısıyla, 1997'de Konya'daki evinde kendisi ile yapılan mülakat önce gazetede yayınlanmış ve daha sonra bu mülakatlar bir kitapta toplanmıştır. Mustafa Bolay'ın esaret hatıraları için bak. Necmeddin Şahiner, "Son Şahitler Onu gören, Konuşan ve Tanıyanların Dilinden Bediüzzaman Said Nursi”, Yeni Asya, Nu: 2595, 27 Nisan 1977, s. 6; Necmeddin Şahiner, Son Şahitler Bediüzzaman Said Nursi'yi Anlatıyor, C. 1, Yeni Asya Yayınları, İstanbul 1993, s.195-197

40 Şahiner, Son Şahitler, s.195

41 Birinci Dünya Savaşında Türk esirleri konusunda hem yapılan araştırmalar ve hem de özellikle ihtiyat zabitleri tarafından savaş sonrasında kaleme alınmıș hatıratlar mevcuttur. Kutlu ve Tașkıran'ın eserlerinin yanı sıra Yücel Yanıkdağ, Millete Deva Olmak Osmanlı Savaş Esirleri, Tıp ve Milliyetçilik, Tarih Vakfı Yurt Yayınları, İstanbul 2014 değerli bir araştırmadır. Yanıkdağ'ın Rusya'daki Türk Esirleri ile ilgili bir başka yayını için bak. Yücel Yanıkdağ, "Ottoman Prisoners of War in Russia 1914-1922, Journal of Contemporary History, Vol. 34, Nu. 1January, London 1999, pp. 69-85. Mahmut Akkor, I. Dünya Savaşında Çeşitli Ülkelerdeki Türk Esir Kampları, Yayınlanmamış Yüksek Lisans Tezi, Sakarya Üniversitesi Sosyal bilimler Enstitüsü, Sakarya 2006 faydalanılabilecek bir diğer araştırmadır.

42 Bu konuda özellikle bak. Cemil Kutlu, "Ermenilerin Türk Savaş Esirlerine Yaptıkları Mezalim”, Türk Dünyası Araştırmaları, S. 131, Nisan 2001, s. 231-234 
bir belgede, aynı taburda birlikte savaştığı Tabip Yüzbaşı Lütfi Bey esirlere yapılan kötü muameleleri rapor edip, anlatmaktadır. ${ }^{43}$

Nihayet Volga kıyısında Kostruma şehrinde bulunan esir kampına götürülmüştür. Mustafa'nın "Orada bir yaz geçirdim." ifadesi, 1917 yazının Kostruma'da yaşandığını göstermektedir. Kampa ilk yerleşmeleri sırasında ihtiyat zabiti olduğunu ispat etmede zorluk çekmesi, bu konuda yerleștirileceği koğuşta bazı subayların tanıdıkları halde sessiz kalmaları, içlerinden bir yüzbaşının duruma müdahalesi ile subay koğuşuna alınması yaşadığı talihsizlik ve zorluklardan sadece bir tanesidir.

Balkan Harbi yıllarında İstanbul'da tanıdığı Said Nursi ile Kotruma'da karşılaşmışlar ve aynı kampa 6 ay geçirmişlerdir. ${ }^{44}$ Menfa yıllarında onu Afyon Emirdağ'da ziyaret de etmiştir. ${ }^{45}$

Kostruma'dan Obi Nehri üzerinde Norini Gulabiç'é ${ }^{46}$ gönderilen Mustafa 3 ay da burada kalacaktır. Bundan sonraki esaret durağının neresi olduğunu gösteren bir belge/bilgi mevcut değildir. Oğlu Süleyman Hayri Bolay’a uzun yıllar önce Kayseri'den mektup gönderen bir şahıs, babasıyla Mustafa’nın aynı kamptan esaret arkadaşları olduğundan bahsetmiştir. Bugün bu mektup bulunamamaktadır. Bolay bu kampın Krasnoyarsk olabileceğini söylemektedir. Bu sadece bir tahmindir. Eğer böyle ise, esaret yolculuğu Sibirya içlerine kadar uzanmış demektir.

Birinci Dünya Savaşı'nda esir düşmüş Türk askerleri, özellikle tahsilli olanlar subay ve ihtiyat zabitleri- esir kamplarını adeta bir mektebe çevirmişler ${ }^{47}$ okumayazma bilmeyen erler eğitilmiş, yabancı dil özellikle Fransızca ve Almanca öğrenilmeye çalışılmış, teksir baskı ile el yazması gazeteler çıkarılmış, ${ }^{48}$ müzik ve temsil faaliyetleri yapılmıștır. Mustafa da esarette, daha sonra yakınlarına mektup yazacak kadar Fransızca öğrenmiștir. ${ }^{49}$

43 ATASE, BDH, K. 2481 D. 486 F. 1-35 (Ek 3 ); aynı arşivde yer alan, Rusya’da Türk esirlere yapılan kötü muameleler için ayrıca bak. BDH. K. 2190 D. 5 F. 7-2; BDH. K. 290 D. 5 F. 7-34

44 Mustafa Bolay'ın Kostruma'daki esaret hayatı ve Said Nursi ile esaret arkadaşlığı bir romanda da yer verilmektedir. Bak. Selçuk Kızıldağ, Nargin Sarıkamış'tan Sibirya'ya, Parafiks Yayınevi, İstanbul 2014, s. 312-318, 400-404

45 Şahiner, Son Şahitler, s.197; Said Nursi'nin Rusya'daki esaret hayatı için bak. Adem Ölmez, Uzun Yürüyüş Belgeler Işı̆̆ında Osmalı’nın Son Yıllarında Bediüzzaman, Nesil Yayınları, İstanbul 2012, s. $143-158$

46 Tüm araştırmalarımıza rağmen arşivlerde, literatürde ve elektronik ortam araştırmalarında bu isme rastlanılmamıştır. Bir kışla ya da semt adı olması muhtemeldir. (YN)

47 Bu hususa örnek bir esir kampı için bak. Cemil Kutlu, "Krasnoyarsk'ın Ölüm Kampından Yatılı Üniversiteye Dönüşmesi “, A. Ü. Türkiyat Araştırmaları Enstitüsü Dergisi, S. 32, Erzurum 2007, s. 245267

48 M. Bülent Varlı,, "Esaret Gazeteleri”, Tarih ve Toplum, C. 34, S. 199, Temmuz 2000, s. 26-28

49 Kostruma ve civarındaki esir kamplarındaki esaret hayatı hakkında daha geniş bilgi için bak. Mehmet Asaf, Volga Kıyılarında ve Muhtıra Esaret Hatıra ve Maceraları, Akademi Kitabevi, İzmir 994; Faik Tonguç, Bir Yedek Subayın Anıları, Türkiye İş Bankası Y7ayını, İstanbul 1999; Mehmet Arif Ölçen, Vetluga Irmă̆ı Çarlık Rusyasında Bir Türk Savaş Tutsă̆ının Anıları, Ümit Yayınevi, Ankara 1994; Cepheden Cepheye Esaretten Esarete (Haz. Eftal Şükrü Batmaz) Kültür Bakanlığı Yayını,Ankara 
Esaret hayatı boyunca ailesi haberleşememiştir. Anlatılanlara göre, babası defalarca Ermenek Askerlik Şubesi'ne giderek oğlundan gelecek haberi beklemiştir. ${ }^{50}$

20 Temmuz 1918'de esaretten avdetle İstanbul'a gelmiştir. Bu yolculuğun iki ay kadar sürdüğü bilinmektedir. Trenle Rusya toprakları geçildikten sonra Varşova, Viyana, Belgrat ve Sofya üzerinden dönmüşlerdir. ${ }^{51}$

Sultanahmet semtinde medrese talebeliği günlerinde alış-veriş yaptığı esnaf Mustafa Efendi’nin dükkânına askere alınırken bazı emanet eşyalar bırakmıştır. Mustafa Efendi, üç yıl süren cephe ve esaret dönemi sonrasında, karşısındaki şahsı tanıyamamış ve ne istediğini sormuştur. Mustafa, ondan aldığı harçlıkla ihtiyaçlarını karşılamış, 7 Kasım 1918 tarihinde terhis edilmiş ve memleketine dönmüştür.

Memleketlerine dönecek ihtiyat zabitlerine Harbiye Nezareti bahçesinde yapılan bir konuşmada; "Artık harbin bittiği, memleketin kötü durumda olduğu, açılan yaraları onların saracağl, çok çalışmaları lazım geldiğ $i$ " hatırlatılacak, memleketlerine dönen bu yorgun savaşçılar çok geçmeden yeniden cepheye vatan müdafaasına çağrilacaklardir.

\section{Mütareke'de}

Memleketinden 1913 yılında medrese tahsili için ayrılan Mustafa esaret sonrasinda İstanbul'dan trenle Konya'ya gelecek ve Hadim üzerinden önce doğduğu köy olan Bolay'a uğrayacaktır. 1907 yılında kaybettiği ablası Huriye'nin oğlu İbrahim 16 yaşında bir gençtir. Aynı yıl hem annesi hem de babasını kaybeden ve küçük yaşlardan itibaren hem öksüz hem de yetim büyüyen İbrahim, sevinç ve heyecanla saatlerce koşarak Dindebol'a gelecek ve dedesi Süleyman Efendi'ye oğlunun esaretten dönüş müjdesini verecektir.

2000. Rusya'da diğer esir kamplarındaki esaret hayatı hakkında ayrıca bak. Hüsamettin Tugaç, Bir Neslin Dramı, Mars Matbaası, Ankara 1966;Metin Tekin, Sarıkamış'tan Sibirya'ya Birinci Dünya Savaşı Anıları, 2. Baskı, Timaş Yayınları, İstanbul 2006; M. Fuad Tokad, Kibrit Kutusundaki Sarıkamış Sibirya Günlükleri, (Haz. Jack Snowden), Timaş Yayınları, İstanbul 2011; Allahüekber Dağlari'ndan Sibirya'ya İrfanoğlu İsmail Efendi'nin Esaret Yılları Hatıraları, (Haz. Ahmet Rıza İrfanoğlu), İstanbul 2004; Ahmet Göze, Rusyada Üç Esaret Yllı (Haz. Ergun Göze), 2. Baskı, Boğaziçi Yayınları, İstanbul 1991; Sarıkamış'tan Esarete Tuğgeneral Ziya Yergök’ün Anıları, (Haz. Sami Önal), 4. Baskı, Remzi kitabevi, İstanbul 2006; Halil Ataman, Harp ve Esaret Doğu Cephesi'nden Sibirya'ya, Türkiye İș bankası Yayını, İstanbul 2011; Hasan Basri Efendi, Bir Gemi Kâtibinin Esaret Hatıraları, (Haz. Bedrettin Görgün), Yapı Kredi Yayınları, İstanbul 2009; İhsan Latif, Bir Serencam-ı Harp, Kültür ve Turizm Bakanlığı Yayınları, Ankara 1998

50 Askeri safahat belgesi ekindeki Ermenek Askerlik Şubesi 6254 numaralı Kütük Künye Defteri’ndeki "Merkum 22 Temmuz 1332 tarihinde mecruhen esir olduğu 9. Kolordu ahzl asker kalemi 02 ăgstos 1332 tarih ve 1166 numaralı tahriratla iş̧ar kılınmıştır." ifadesi, aslında esaret bilgisinin resmi kayıtlara girdiğini göstermektedir.

51 Rusya'daki Türk esirlerinin yurda döndürülmeleri çalışmaları için bak. Kutlu, Rusya'da Türk Esirleri, s. 365-402; bu konuda İsveç Kızılhaçı'nın çalışmaları için bak. Tülin Uygur, I. Dünya Savaşı'nda Esir Türkler, Kaynak Yayınları, İstanbul 2014, s. 167-202 
Oğlu İsa'yı Çanakkale'de kaybeden baba, Mustafánın dönüşüyle üzüntüsünden kurtulacaktır. Onun, oğlu Mustafa'dan ümidini kestiği ve şehit olduğunu düşündüğü günlerde ablası Şerife'nin;

“Unuttun mu sen Allah'

Oğlun sağdır vallahi” sözleriyle başlayan tesellisi, ailenin harp yılları hatıralarındaki yerini hâlâ muhafaza etmektedir.

1919 Haziran'ında köyde ikamet etmekte olduğu, Köy İhtiyar Heyeti tarafından Ermenek Askerlik Şubesi'ne bildirilmiş ve bu durum kayıt altına alınmıștır. ${ }^{52}$

1920 Ekim'inde Konya bölgesinde ortaya çıkan Delibaș İsyanı sırasında, isyancılar Aslanoğlu'nun liderliğinde Bolay üzerinden gelirler ve Dindebol'u işgal ederek, burada kamp kurarlar. Tecrübeli bir asker olması sebebiyle isyancılar tarafından kendilerine ve Ermenek'e yapılacak baskına katılmaya zorlanır. Bu baskıyı bertaraf eder, ${ }^{53}$ isyancılar başarısız olur ve elebaşı olan Aslanoğlu 19 Ekim'de Ermenek'te idam edilir. $^{54}$

Mondros Mütarekesi sonrasında ülkede ortaya çıkan işgaller ve bu duruma karşı başlatılan Milli Mücadele, seferberlik ve esaret yıllarından sonra memleketinde ailesinin yanındaki Mustafa'yı, diğer ihtiyat zabitleri gibi yeniden vatan hizmetine çağrilmasina sebep olacaktır.

\section{Milli Mücadele'nin Mücahidi}

Öğretmen Sicil Dosyasında yer alan ifadesiyle; içinde yer alacağı savaş yılları artık bir "Milli Mücahede"dir. O, Türk milletinin içinde bulunduğu şartları ve verdiği mücadeleyi cihad olarak görmektedir. 1921 yazında Anadolu'da Yunan ilerleyiși üzerine yeni bir seferberlik hali yaşayan Türk milleti adına Ankara hükümeti Mondros sonrası alınan terhis kararını tanımayacak, seferberliğin devam ettiğini duyuracaktır.

20 Mayıs 1921 tarihinde İstiklal harbinde yeniden tavzif edilecek; Konya Askerlik Dairesi'nce Şark için Karaman'da tertip edilen Menzil Kolu'nda vazife verilecektir. ${ }^{55}$ Bu tarihlerde memleketi Konya'da bulunan bazı ihtiyat zabitlerinin de Batı Cephesi için teşkil olunan menzil kollarında görev yaptığı görülmektedir. ${ }^{56}$

52 Askeri Safahat Belgesi, 14 Haziran 2013/2958

53 Bu bilgiler torunu, ağabeyim İsmail Arıkan tarafından aktarılmıștır.

54 Halit Bardakçı, Bütün Yönleriyle Ermenek, Çaba Matbaası, Konya 1976, s. 63-67

55 Askeri Safahat Belgesi, 14 Haziran 2013/2958

56 Misır'daki esaret hayatından sonra memleketi Konya'ya dönen Hulusi Turgut Garbi Anadolu menzil Müfettişliği emriyle Batı Cephesi için Karaman'da oluşturulan menzil kolunda, deve teşkilatı kurarak Balıkesir'e cephane götürmekle görevlendirilmiştir. Bak. Arif Nüshet Turgut, "Bir Konyalı Subay ve Esaret Hatıraları", Yeni İpek Yolu Dergisi Konya Kitabı VII, Konya 2004, s. 62 
6 Temmuz 1921'de Ankara Talimgâhına dâhil olmuş, 22 Ağustos'ta zabit namzedi olarak buradan ayrılmış, 22 Ağustos'ta Garp Cephesinde 5. Kafkas Tümeni 13. Alay 9. Bölük'e tayin edilmiștir. ${ }^{57}$ Kendi ifadesine göre Sakarya, Afyonkarahisar, Resulbaba, Başkomutanlık Meydan Muharebelerine muharip olarak katılmıștır. 7 Ocak 1922'de fedakârlı̆̆ına binaen bir derece terfi ile taltif olunmuştur. ${ }^{58}$

Savaş sonunda 3 Mayıs 1923'te teğmen rütbesine terfi etmiş ve 31 Temmuz 1923'te terhis olmuş ve memleketine dönmüştür. ${ }^{59}$

Mustafa'nın cephede savaştığı günlerde, amcazadesi Mehmet Emin (Bolay) Konya'da çıkardığı İbret isimli gazete ile Milli Mücadele'ye destek vermiş, Konya Müdafaa-i Hukuk Cemiyeti faaliyetlerine iştirak etmiştir. Ağabeyi İsa Ruhi (Bolay) de aynı tavrı göstermiștir. Müderris İsa Ruhi Efendi, aynı zamanda Müdafaa-i Hukuk Cemiyeti kurucularından ve azalarından Gilisıralı Hacı Tahir Efendi'nin damadıdır. ${ }^{60}$

17 Ağustos 1971'de İstiklal Madalyası ve ile ödüllendirilecektir. ${ }^{61}$

\section{Öğretmenlik Yılları ve Cehaletle Mücadele}

Terhisinden sonra 8 Ağustos 1923 tarihinde 334 sayıl tasdikname ${ }^{62}$ ile talebeliğine son veren Mustafa 1924 Eylülünde Konya İlk Tedrisat Müdürlüğü’nde girdiği imtihanı başaracak ve muallim yardımcısı ehliyetnamesi alacak, 20 Mayıs 1926'da ilgili kanun mucibince muallim sayılacaktır.

O, Türkiye Cumhuriyeti'nin köyüne tayin ettiği ilk öğretmendir. Köyde ilk mektebin açılmasıyla, köyün mektebe giden çocukları, kilometrelerce yürüyerek Lafsa (Kirazlıyayla) köyüne gidip gelmekten kurtulacaklardır. Bu çocuklardan birisi de sonradan damadı olacak Mehmet Kamil Arıkan (1914-2000)'dır. Çocukların tahsil göreceği mektep binasının temini, inşası, tamiri ile de uğraşacaktır.

Balkan Savaşının acı sonuçlarını bizzat İstanbul'da görmüş, Birinci Dünya Savaşı ve Milli Mücadele'ye muharip asker olarak katılmış, esir düşmüş, mütarekenin menfi

57 Askeri Safahat Belgesi, 04 Ekim 2012/4860

58 KIMEMA SDN 253, Memurin Tercüme-i Hal Varakası

59 Askeri Safahat Belgesi, 04 Ekim 2012/4860

60 Mustafa Arıkan, "Milli Mücadele'ye Konya'dan Bir Destek: Hâdimizade Mehmet Emin ve Gezetesi İbret", Uluslararası Milli Mücadele ve Zafer Yolu Sempozyumu, C. II, Atatürk Araștırma Merkezi Yayını, Ankara 2014, s. 719-754

61 Emekli Sandığı Arşivi, SDN Vo.572.502.0. Torunu Hüzeyme Yeşim Koçak’ın yazdığı ve İlesam-Akçağ 2010 Roman Yarıșmasında birincilik ödülü almıș hatırat-romanda bu istiklâl madalyasına "Köy evinin en mutena kössesinde 'İstiklâl Madalyası' dururdu. Babanın bütün ömrü o madalyayı bi hakkın almak ve şerefle taşımak için geçmiş gibiydi." sözleriyle atıfta bulunulmaktadır. Bak. Hüzeyme Yeşim Koçak, Sarılmak, Akçağ Yayınları, Ankara 2011, s. 8. Roman hakkında bir değerlendirme yazısı için ayrıca bak. Nurullah Çetin, "Hüzeyme Yeşim Koçak'ın Sarılmak Romanını Tahlil”, Türkish Studies, S. 6/3, Yaz 2011, s. 83-92

62 Tasdikname belgesi için bak. Ek 2 
olaylarını köyünde bile yaşamak zorunda kalmış tecrübeli bir insan olarak; talebelerine, milletin böyle kötü zamanları tekrar yaşayabilme ihtimaline karşı, yaşlarına uygun bir askeri eğitim vermeye çalışmıştır. Talebesi ve damadı Arıkan'ın anlattığına göre, bu eğitimleri kendilerinin imal ettikleri tahta tüfekler ile yapmışlardır. Dönemin ruhuna uygun olarak, ilk mektep talebelerini millet-i müselleha anlayışının bir yansıması olarak, küçük birer asker olarak yetiștirmek istemiștir.

Öğrencilerine ilk mektep tedrisatının gerektirdiği dersleri okutmanın yanı sıra onlara dini bilgileri vermiş, milli bir ruha sahip olmalarına da gayret etmiştir. $\mathrm{Mu}-$ allimlik yıllarında milli bayramların, gerçek bir bayram havası içinde kutlanmasını sağlamıştır.

6 Ekim 1924'te Dindebol'da başlayan muallimlik hayatı Bolay, Davdas, Uğurlu, Gezlevi, Karkın, Kavak, Eğribayat gibi Konya’nın köylerinde devam edecek, 13 Temmuz 1959'da Konya Şehit Sadık İlkokulu'nda sona erecektir. ${ }^{63}$

Muallim Mustafa Bolay'ın, ilk görev yeri olan Dindebol'da yaşadıklarına bakıldığı 1 zaman, cehaletle mücadelesinin mektep ile sınırlı kalmadığı görülmektedir. Sicil dosyasında yer alan bir tahkitata ait evrak onun bu konuda yaşadıklarını gözler önüne sermektedir.

1927 yllı güzünde kardeşi Osman, tarlada çalışırken köyden birileri tarafından saldırıya uğrar, ağaç üzerinde bulunduğu için kendisini müdafaa edemez, başına isabet eden bir taşla ağır yaralanır. Ağabeyi Çanakkale'de şehit olan muallimin kardeşi Osman da ölümle karşı karşıyadır. Olayı müteakip, dava açmak, doktor getirmek ya da izin almak gibi sebeplerle Ermenek'e gitmek zorunda kalır. Bunu firsat bilen bazıları hemen bir dilekçe kaleme aldırtarak kendisini önce Konya Maarif Emaneti'ne sonra da Ankara'da Maarif Nezareti'ne şikâyet ederler. İçlerinde önceden muhtarlık, halen köy heyeti reisliği yapan ve köy heyeti azalarından bazıları da vardır. Mektep talebelerinin bazılarının da dilekçe altına isimleri yazılır. Vazifesini yapmamakla, okulu kapalı tutmakla ve hatta "Mustafa Efendi evvelce mektep görmeyip ve mektep usulü bilmediği gibi mümaileyh bir medrese bozmasıdır." ifadesiyle de suçlanır. Şikâyetçiler Şark kurnazlı̆̆ yapmakta, dönemin havasından istifade etmeye çalışmaktadırlar. $\mathrm{O}$, bu haksız suçlamalara "Hususi ve resmi tahsilim Fevziye Mektebinden mezun bir muallimden aşağı değildir. İhtiyat mülazımıyım. Ruhen de Cumhuriyetin fezâil ve inkılâbın îcâbâtını hazm ve temsil eden bir muallimim. Hakkımda dil uzatanlar aksi haldeki kötü beyinlerdir." şeklinde cevap vermiştir.

Tahkikat sırasında müfettişin ifadesine başvurduğu dokuz kişiden sekizinin okuma-yazma bilmiyor olması, meselenin trajikomik yanının ifadesidir. Bu durumun sebebi, içlerinden birisinin muallim olarak köye gelmesi, devletten maaş alması,

63 KİMEMA SDN 253, Hizmet Çizelgesi 
köyden mal-mülk edinmesi ve özellikle -kanun icabı- köy halkını çocuklarını okula göndermeye zorlaması, göndermeyenlerin para ile cezalandırılmasını sağlamasıdır.

Konya Mıntıkası Maarif Eminliği 9 Şubat 1928 ve 281 sayılı nihai kararında; şikâyetnamede belirtilen hususların kati surette sabit olmadığı, geçerli mazereti sebebiyle izinli olarak Konya'da kardeşi ile ilgilendiğinin tespit edildiğini, vazifesinde daha dikkatli olması hususunda kendisinin ihtar edilmesinin yeterli olacağı sonucuna varmıştır. ${ }^{64}$

Ablası Huriye'yi 1907 yılında 25 yaşında, ağabeyi İsa'yı Çanakkale'de, küçük kardeşi Osman'ı da cehaletin elinden atılan bir taşla 1927 yılında Konya'da Kolordu Hastanesi’nde kaybedecek; acıları savaş yıllarıyla sınırlı kalmayacaktır.

\section{Evliliği, Çocukları ve Ölümü}

Köyünde muallim olarak göreve başladıktan sonra, 1924 yılında Fatma Hanım ile evlenecektir. İlk çocuğu Huriye (01.11.1926-05.06.1989) -nüfus kayıt örneğindeki bilgiye göre- 1926 yılında dünyaya gelecek, fakat Huriye henüz bir yaşını geçmişken genç yaşta annesi vefat edecek, kendisi ve babası yalnız kalacaktır.

Kardeşi Osman'ın 1927 yılında kurtarılamayarak ölmesi sonucunda, o da geride henüz bir yaşındaki oğlu Osman ve eşi Hüzeyme'yi bırakacaktır. Kardeşinin ölümünden üç yıl sonra, geleneğin bir icabı olarak, kardeşinin eşi Hüzeyme Hanım (1908-08.08.1951) ile evlenecektir. Bu evliliğinden sırasıyla diğer çocukları İsa Ruhi (20.12.1931), Fatma Zehra (20.12.1931), ${ }^{65}$ Ayşe Sıddıka (18.01.1934), Süleyman Hayri (02.02.1937) ve Mehmet Naci (10.09.1942-10.05.2001) olacaklardır. ${ }^{66}$

Hüzeyme Hanım'ın vefatından sonra üçüncü evliliğini Hadim’li Ayşe Hanım (1899-1959) ile yapacaktır. Yine bir ölümle bitecek olan bu evlilik, 1959 yılında bir başka hanım ile hayatını birleştirmek zorunda bırakacaktır.

Oğulları ve kızlarından yirmi üç torun sahibi olan Bolay, sağlığında bazı torun çocuklarını da görecektir.

O çocuklarının hepsini okutacak; dönemin ve yaşanılan vasatın, belki de geleneğin icabı olarak kızların ilk tahsilleriyle iktifa edilecektir. Oğulları İsa Ruhi, Süleyman Hayri ve Mehmet Naci Dindebol köyünün ilk yüksek tahsilli gençleri olacaktır. İsa Ruhi bürokraside genel müdürlük seviyesinde vazife yapacak, Süleyman Hayri Felsefe, Mehmet Naci Mantık profesörü seviyesine yükseleceklerdir.

64. KİMEMA SDN 253, 9 Şubat 1928 tarih ve 281 sayılı tahkikat nihai kararı

65 Zehra, İsa Ruhi'den küçük olmasına rağmen, nüfus kaydında doğum tarihleri aynıdır. Bu durum, çocukların doğumlarından birkaç yıl sonra nüfusa birlikte kayıt edilmelerinden kaynaklanıyor olsa gerektir. (YN)

66 Bu araştırmada aile fertlerinin nüfus kaydı bilgileri için Meram Nüfus Müdürlüğü, Nüfus Kayıt Örneği (18.09.2012)'nden istifade edilmiştir. 
Öğretmen emeklisi olarak Konya'da sade bir hayat yaşayacak, torunlarının yetişmesine de katkı sağlayacak, dini ve milli terbiye edinmelerini temine çalışacak, ailenin fikrine saygı gösterilen, danışılan büyüğü olarak kızı Zehra Koçak'ın evinde 27 Eylül 1981 Pazar günü gecesi Hakk'ın rahmetine kavuşacaktır.

\section{Sonuç}

On yıllık savaş sürecinin ve özellikle seferberlik yıllarının acılarının, evlatlarını vatan için cepheye gönderen ailelerin, anaların içinde bulunduğu durum Zeytindağı'nda, bir Anadolu istasyonunda cepheden dönenlere sorulan "Benim Ahmed'i gördünüz mü?” sorusunda ve Atay'in müteakip satırlarında ifadesini bulmaktadır. ${ }^{67}$ Vatan için Çanakkale'de İsa'yı şehit veren, Mustafa'nın ise cephelerden ve esaretten dönüş yolunu gözleyen Süleyman Efendi ve Fatma Hanım’nn, diğer oğulları Osman da savaş sonrası yıllarda cehaletin elinden fırlatılan bir taşa kurban gitmiştir. Tıpkı dedesi Büyük Hacı İsa Efendi gibi. ${ }^{68}$ Kızları Huriye de genç yaşında bırakıp gitmiștir onları.

Popüler tarih romanları yazarı Morkaya İhtiyat Zabitinde seferberlikte ihtiyat zabit namzetliği için müracaat eden medrese talebelerini "Fatih ve Sultanahmet medreselerindeki çömezler" olarak adlandırıp mektepliler ile kıyaslayarak onları adeta aşağllayacaktır. Mektepliler onlara nazaran "iyi terbiye görmüsş yüksek aile evlatları"dır; diğerleri ise "yağll ve böcekli medrese mahsulü"dür. Üstelik bunlar doğru-dürüst okuma-yazma bile bilmezler. ${ }^{69}$ Mektep-medrese konusunda ciddi akademik tartışmalar yapılabilir; mektep lehine bir sonucun çıkacağı da muhakkaktır. Modernleşme hamleleri içerisinde bulunan Darülhilafe mensubu talebeler için Morkaya'nın yaptığı tespit bir bühtandır. Bu değerlendirmenin tekzibi; birçok örneğinde görülebileceği üzere, İsa ve kardeşi Mustafa'nın hayat hikâyesidir. Medreselerin kaldırıldığı sene, savaş yıllarında tanınmış bir hakkın teslimi olarak Mustafa köyüne muallim olarak gönderilmişti. Bu cümleden olarak; medrese mensuplarının yeni Türk devletinin kuruluşuna ve Cumhuriyet'e yaptığı katkılar bir akademik araştırmanın konusu olmalıdır.

Şehitlerimiz hususunda yapıldığı gibi, ilgili kurumlar Birinci Dünya Savaşı’nda Türk esirlerinin tespiti için de benzeri çalışmaları yapmalıdır. ${ }^{70}$ Ayrıca şehitlerimiz konusunda yapılan çalışmalardaki yanlışlar, devam eden süreçte düzeltilmelidir. İnternet ortamı, Şehitlerimiz adlı eser ve Milli Savunma Bakanlığı Arşivi’ndeki kayıtlar arasında tutarsızlıklar ortaya çıkabilmektedir. İsa’nın şahadet tarihinde olduğu gibi.

67 Falih Rıfkı Atay, Zeytindağı, Milli Eğitim Bakanlığı Yayını, İstanbul 1989, s. 113-114

68 Bolay'da su meselesinden kavga eden köylüleri yatıştırmak isterken kafasına isabet eden bir taşla hayatını kaybetmiştir.

69 Morkaya, İhtiyat Zabiti, s. 17-19

70 Arşivlerde yapılan taramalarda Rusya'daki Türk esir subayların listeleri ile ilgili sağlıklı bir sonuca ulaşılamamaktadır. Kızılay Arşivi'nde bu konuda Berezofka Esir Kampı'na ait sadece iki listeye rastlanılmıştır. Kızllay Arşivi, Belge Nu: 562/3.1-562/3. 2; 562/5, 8.4.1918 
Savaş yılları ile ilgili yapılabilecek bir başka tespit Türk ad koyma geleneği ile ilgilidir. Şehit İsa müteselsil olarak dedelerinin ismini taşımaktadır. Savaş sonrasında kardeşi Mustafa, doğan ilk erkek çocuğuna babasının değil, şehit ağabeyinin ismini vermiştir. Bu teselsül ve geleneği şahadet bozmaktadır. ${ }^{71}$

Savaş yıllarında ve özellikle Çanakkale cephesinde bir tahsilli nesil kaybettik. Savaştan dönebilenler Türkiye Cumhuriyeti'ne; onun temellerine önce savaşarak daha sonra da aldıkları vazifeler ile katkıda bulundular. Azalan nüfusu çoğaltmak, "on yılda on beş milyon genç yaratmak" idealinin yükseltildiği yıllar ve sonrasında, devam eden nesilleriyle Türkiye'ye katkıda bulundular. ${ }^{72}$ Cemiyete rehberlik ettiler. Mustafa örneğinde olduğu gibi.

İsa ve Mustafa'nın şahsında bütün şehit ve gazilerimizi rahmetle, minnetle anıyor, ruhlarına Fatihalar gönderiyoruz.

71 Bu durumun bir başka örneği için bak. Mustafa Arıkan, "Bir Çanakkale Şehidi ve Mektubunun Başına Gelenler", Gazi Akademik Bakış, C. 5, S. 9, Kıș 2011, s. 213-243

72 Türkiye'nin savaşlar sebebiyle azalan ve ciddi sağlık sorunlarıyla uğraştığı yılların ortaya çıkardığı öjeni meselesi ve uygulamaları için bak. Yanıkdağ, Millete Deva Olmak, s. 263-291 


\section{KAYNAKÇA}

\section{Arşiv Belgeleri}

Askeri Tarih ve Stratejik Etüt Dairesi Başkanlığı Arşivi (ATASE)

Konya İl Milli Eğitim Müdürlüğü Arşivi (KİMEMA)

Kızılay Arşivi

İstanbul Müftülüğü Şer'iyye Sicilleri Arşivi

\section{Kitaplar ve Makaleler}

Aksakal, Mustafa, Harb-i Umumi Eșiğinde Osmanlı devleti Son Savașına Nasıl Girdi, İstanbul Bilgi Üniversitesi Yayını, İstanbul 2010

Albayrak, Sadık, Son Devir Osmanlı Uleması (İlmiye Ricalinin Teracim-i Ahvâli), C. 3, İstanbul Büyükșehir Belediyesi Yayınları, İstanbul 1996

Allahüekber Dağları'ndan Sibirya'ya İrfanoğlu İsmail Efendinin Esaret Yılları Hatıraları, (Haz. Ahmet Rıza İrfanoğlu), İstanbul 2004

Arıkan, Mustafa, "Bolaylar", Konya Ansiklopedisi, C. 2, Konya 2011, s. 154-158 , "Milli Mücadele'ye Konya'dan Bir Destek: Hâdimizade Mehmet Emin ve Gezetesi İbret", Uluslararası Milli Mücadele ve Zafer Yolu Sempozyumu, C. II, Atatürk Araștırma Merkezi Yayını, Ankara 2014, s. 719-754

, "Bir Çanakkale Şehidi ve Mektubunun Başına Gelenler", Gazi Akademik Bakış, C. 5, S. 9, Kiş 2011, s. 213-243

Asaf, Mehmet, Volga Kıyılarında ve Muhtıra Esaret Hatıra ve Maceraları, Akademi Kitabevi, İzmir 994

Falih Rıfkı Atay, Zeytindağı, Milli Eğitim Bakanlığı Yayını, İstanbul 1989

Ataman, Halil, Harp ve Esaret Doğu Cephesi’nden Sibirya'ya, Türkiye İş bankası Yayını, İstanbul 2011

Bardakçı, Halit, Bütün Yönleriyle Ermenek, Çaba Matbaası, Konya 1976

Birinci Dünya Harbinde Türk Harbi Kafkas Cephesi 3ncü Ordu Harekatı C II, ATASE Yayını, Ankara 1993

Cepheden Cepheye Esaretten Esarete (Haz. Eftal Şükrü Batmaz) Kültür Bakanlığı Yayını, Ankara 2000

Çetin, Nurullah “Hüzeyme Yeşim Koçak'ın Sarılmak Romanını Tahlil”, Türkish Studies, S. 6/3, Yaz 2011, s. 83-92

Erdemir, Lokman, Çanakkale Bir Milletin Varoluş Destanı, Çamlıca Yayınları, İstanbul 2011

Erickson, Edward J., Size Ölmeyi Emrediyorum Birinci Dünya Savaşı'nda Osmanlı Ordusu, Kitap Yayınevi, 2. Baskı, İstanbul 2003

Göze, Ahmet, Rusyada Üç Esaret Yılı (Haz. Ergun Göze), 2. Baskı, Boğaziçi Yayınları, İstanbul 1991 
Hasan Basri Efendi, Bir Gemi Kâtibinin Esaret Hatıraları, (Haz. Bedrettin Görgün), Yapı Kredi Yayınları, İstanbul 2009

İhsan Latif, Bir Serencam-ı Harp, Kültür ve Turizm Bakanlığı Yayınları, Ankara 1998

Kızıldağ, Selçuk, Nargin Sarıkamış'tan Sibirya'ya, Parafiks Yayınevi, İstanbul 2014

Koçak, Hüzeyme Yeşim, Sarılmak, Akçağ Yayınları, Ankara 2011

Kutlu, Cemil, "Ermenilerin Türk Savaş Esirlerine Yaptıkları Mezalim”, Türk Dünyası Araştırmaları, S. 131, Nisan 2001, s. 231-234

, Cemil, “Krasnoyarsk'ın Ölüm Kampından Yatılı Üniversiteye Dönüşmesi “, A. Ü. Türkiyat Araştırmaları Enstitüsü Dergisi, S. 32, Erzurum 2007, s. 245-267

Kütükoğlu, Mübahat, “Darü’l Hilafeti'l Aliyye medresesi ve Kuruluşu Arefesinde İstanbul Medreseleri”, İslam Tetkikleri Enstitüsü Dergisi, S. 7/1-2'den ayrı basım, İstanbul 1978, s. 3-4

Morkaya, Burhan Cahit, İhtiyat Zabiti, Kanaat Kütüphanesi, İstanbul 1933

Ölçen, Mehmet Arif, Vetluga Irmağı Çarlık Rusyasında Bir Türk Savaş Tutsağının Anıları, Ümit Yayınevi, Ankara 1994

Ölmez, Adem, Uzun Yürüyüş Belgeler Ișığında Osmalı'nın Son Yıllarında Bediüzzaman, Nesil Yayınları, İstanbul 2012

"Prof. Dr. Süleyman Hayri Bolay İle Söyleşi”, (Haz. Ethem Cebecioğlu, Vahit Göktaş, Sevim Yllmaz), Tasavvuf, Yıl: 9, Sayı: 22 (Temmuz-Aralık 2008), s.393-428

Rusya Üsera Murahhası Yusuf Akçura Bey'in Raporu, Dersaadet 1335

Sarıkamış'tan Esarete Tuğgeneral Ziya Yergök'ün Anıları, (Haz. Sami Önal), 4. Baskı, Remzi Kitabevi, İstanbul 2006

Sural, Mahmut, “50 Yıl Önceden Bu Yana Her Yönüyle Konya”, Yeni Konya, 19 Eylül 1975, s. 3; Uyar, Hattatlar Armağanı, s. 24-25

Şahiner, Necmeddin, “Son Şahitler Onu gören, Konuşan ve Tanıyanların Dilinden Bediüzzaman Said Nursi”, Yeni Asya, Nu: 2595, 27 Nisan 1977, s. 6

, Son Şahitler Bediüzzaman Said Nursi'yi Anlatıyor, C. 1, Yeni Asya Yayınları, İstanbul 1993

Taşkıran, Cemalettin, Ana Ben Ölmedim 1. Dünya Savaşında Türk Esirleri, Türkiye İș Bankası Yayınları, İstanbul 2001

Tekin, Metin, Sarıkamış’tan Sibirya'ya Birinci Dünya Savaşı Anıları, 2. Baskı, Timaş Yayınları, İstanbul 2006

Tokad, M. Fuad, Kibrit Kutusundaki Sarıkamış Sibirya Günlükleri, (Haz. Jack Snowden), Timaş Yayınları, İstanbul 2011

Tolon, Ahmet Hurşit, Birinci Dünya Savaşı Sirasında Taksim Anlaşmaları ve Sevr'e Giden Yol, Atatürk Araştırma Merkezi Yayını, Ankara 2016

Uçarol, Rifat, Siyasi Tarih (1789-1994), 4. Baskı, Filiz Kitabevi, İstanbul 1995

Tonguç, Faik, Bir Yedek Subayın Anıları, Türkiye İş Bankası Yayını, İstanbul 1999

Tugaç, Hüsamettin, Bir Neslin Dramı, Mars Matbaası, Ankara 1966

Turgut, Arif Nüshet, "Bir Konyalı Subay ve Esaret Hatıraları", Yeni İpek Yolu Dergisi Konya Kitabı VII, Konya 2004, s. 62

Uyar, Veli Sabri, “Hattatlar Armağanı”, Konya, Sayı 125-126, Mart_Nisan 1949, Yıl XIII, s.24-25

Uygur, Tülin, I. Dünya Savaşı’nda Esir Türkler, Kaynak Yayınları, İstanbul 2014 
Varlık, M. Bülent, "Esaret Gazeteleri”, Tarih ve Toplum, C. 34, S. 199, Temmuz 2000, s. 26-28

Yanıkdağ, Yücel, “Rusya'daki 90 bin Osmanlı Savaş Esiri ve Sarıkamıș Muharebesi”, Taraf, 7 Ocak 2015, s. 10

Yanıkdağ, Yücel, Millete Deva Olmak Osmanlı Savaş Esirleri, Tip ve Milliyetçilik, Tarih Vakfı Yurt Yayınları, İstanbul 2014

" "Ottoman Prisoners of War in Russia 1914-1922, Journal of Contemporary History, Vol.

34, Nu. 1January, London 1999, pp. 69-85

\section{Tezler}

Akkor, Mahmut, I. Dünya Savaşında Çeşitli ülkelerdeki Türk Esir Kampları, (Yayınlanmamış Yüksek Lisans Tezi), Sakarya 2006

Kutlu, Cemil, I. Dünya Savaşında Rusya'daki Türk Esirleri ve Bunların Yurda Döndürülme Faaliyetleri, (Yayınlanmamıș Doktora Tezi), Erzurum 1997.

Sabah, İsmail, Çanakkale Savaşlarının Eğitim Kurumuna Etkisi (1914-1916), (Yayınlanmamış Yüksek Lisans Tezi), Çanakkale 2013

\section{İnternet Adresleri}

http://www.msb.gov.tr/arsiv/phpscr/Sehitler.php 
Ekler

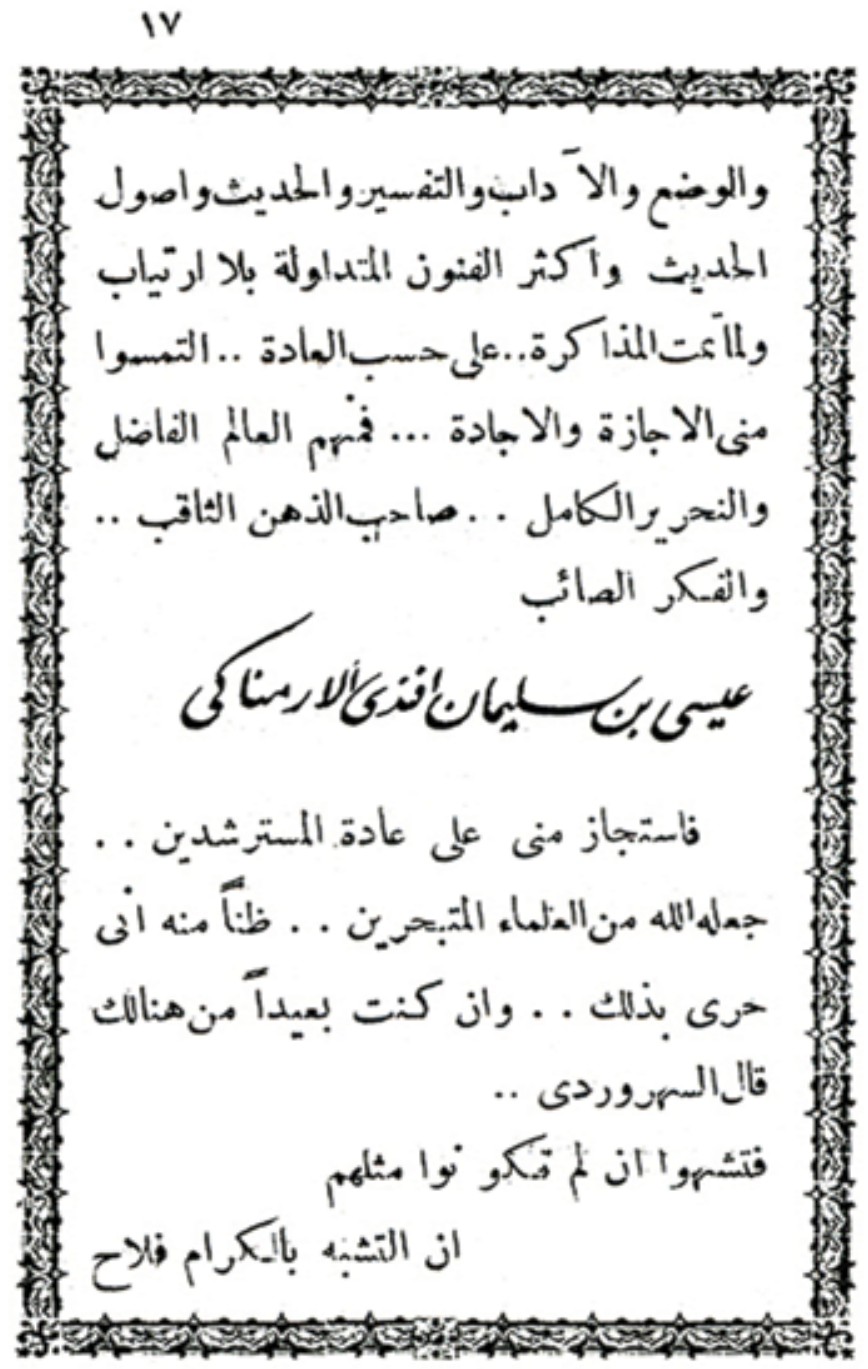

Ek 1. Çanakkale Şehidi İsa'nın İcazetnamesi 


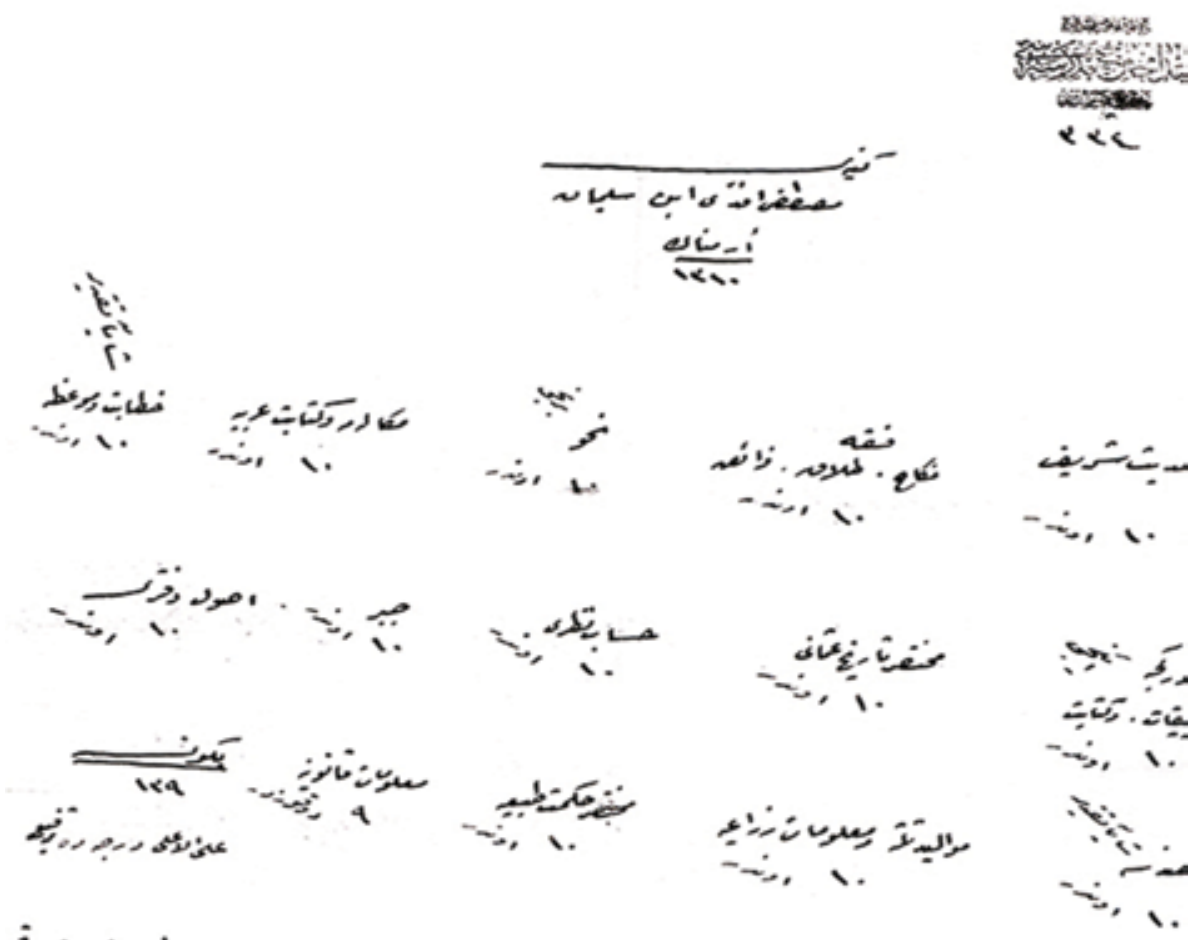

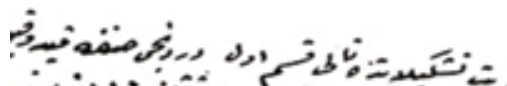

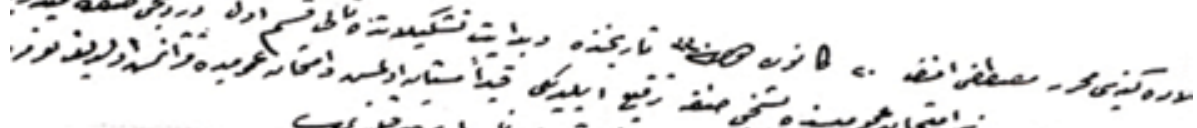
20. 迸

Ek 2. Mustafa (Bolay)'ın 1924 Yılında Aldığı Tasdikname 


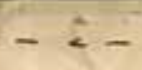

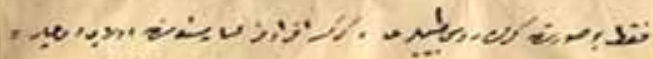

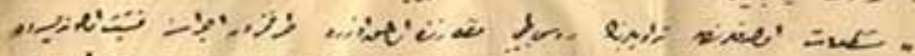

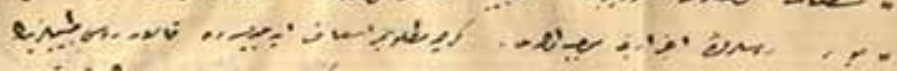

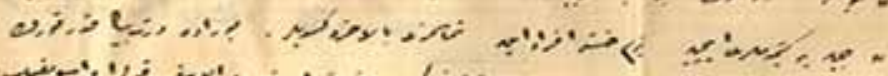
"

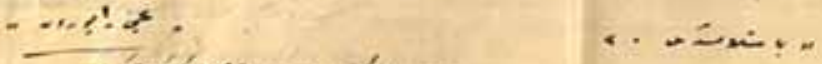

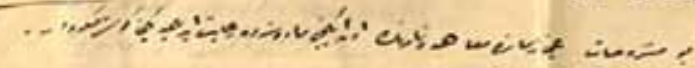

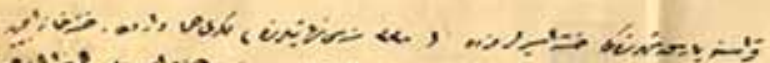

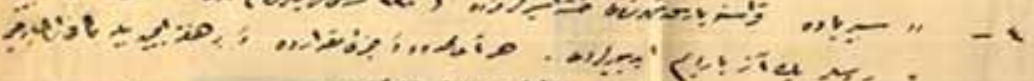

Pestic

$$
\begin{array}{|l|l|}
\hline 1 & 1-2 \\
\hline 0 & \\
\hline 5 & 1-59 \\
\hline
\end{array}
$$

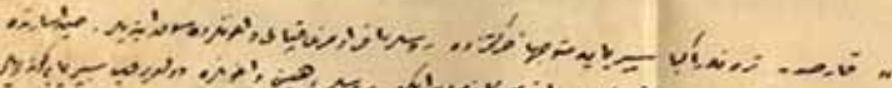

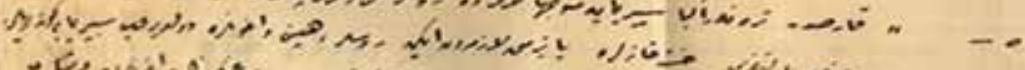

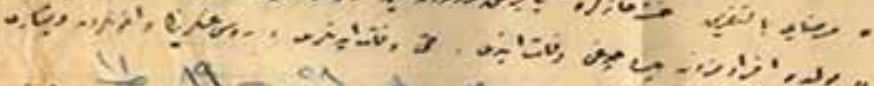

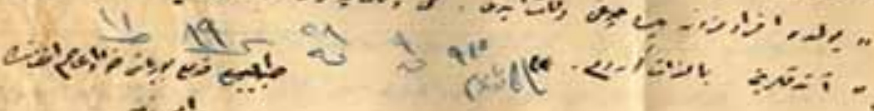

< istic

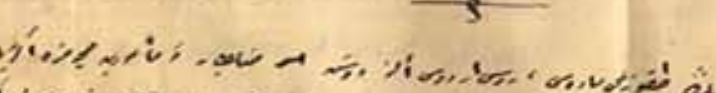

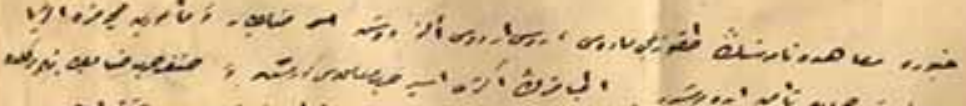

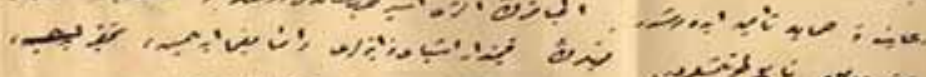

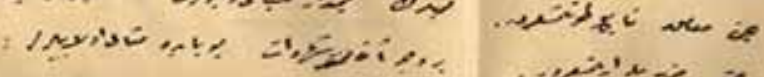

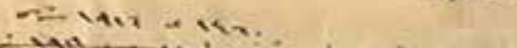

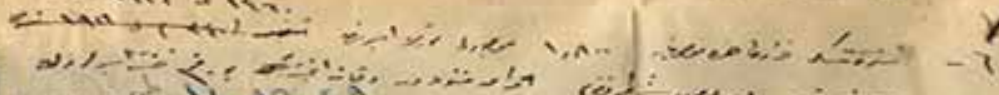

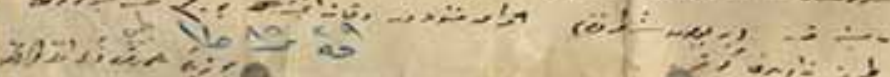

Ek 3. Rusya'da Türk Esirlerine Yapılan Kötü Muameleye Dair Bir Belge 

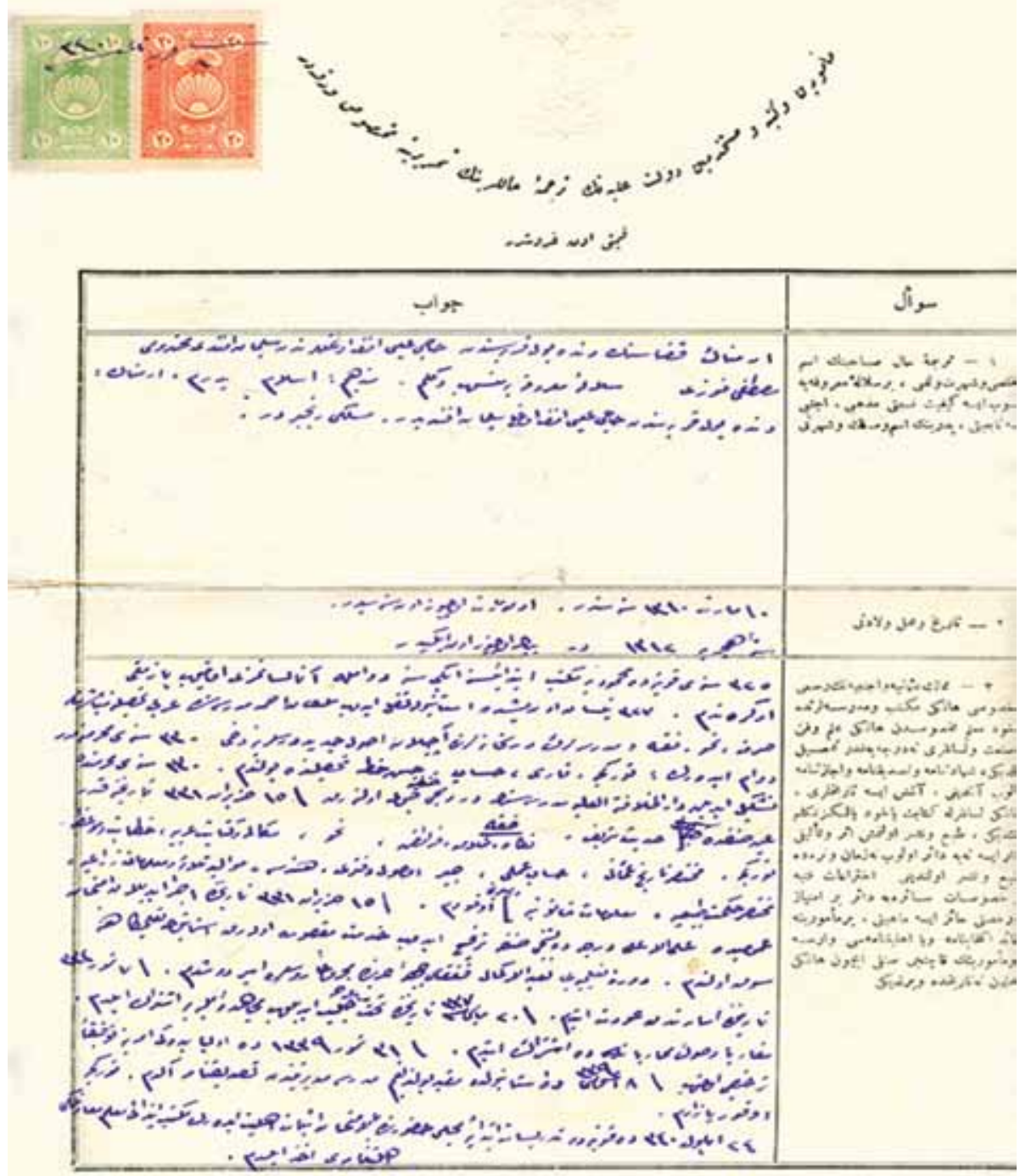

Ek 4. Mustafa (Bolay)'ın Öğretmen Sicil Dosyasında Tercüme-i Hâl Varakasından Bir Sayfa 


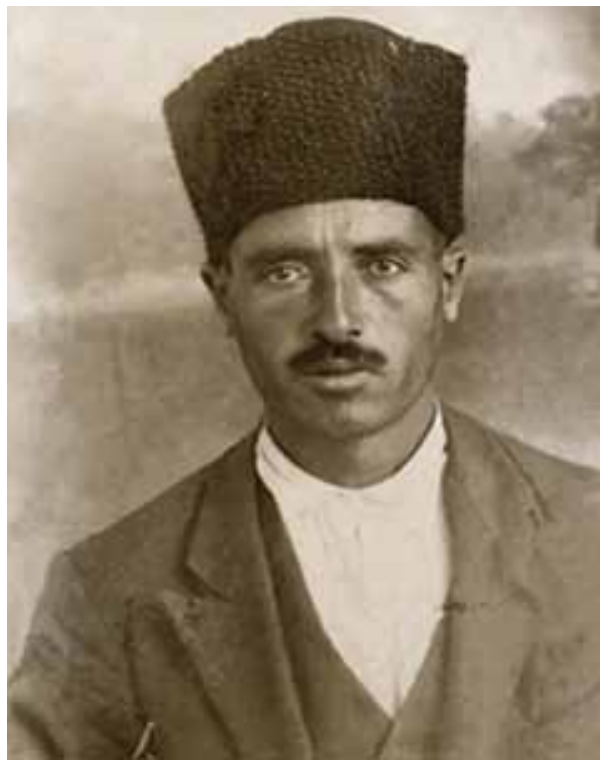

Ek 5. Mustafa (Bolay)'ın Milli Mücadele Sonrasından Bir Resmi

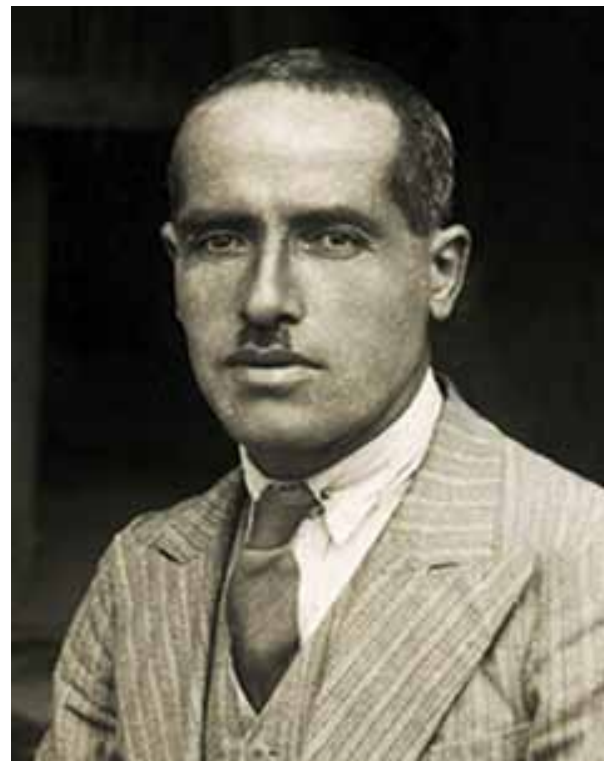

Ek 6. Mustafa Bolay Öğretmenlik Yıllarında 